\title{
ВНУТРИПОЛИТИЧЕСКИЕ КОНФЛИКТЫ
}

\author{
Филиппов B.P., Ажунусбаев С.М.
}

\section{ИВУАРИЙСКИЙ КРИЗИС 2010-2011 ГОАОВ: ПРИЧИНЫ МНИМЫЕ И РЕААЬНЫЕ}

\begin{abstract}
Аннотация. Используя метод исторической реконструкции, авторы показывают латентные причины вооруженного конфликта между мусульманским «Севером» и христианским «Югом» в Республике Кот-д’Ивуар в 2010-2011 г2. Комплексный анализ широкого круга источников (материалов СМИ, судебных и журналистских расследований, свидетельств известных политиков и дипломатов) позволил обосновать точку зрения, согласно которой интерпретация этого конфликта в качестве «межэтнического» не имеет под собой достаточных оснований. Предлагается рассматривать ситуацию в Кот-д’'Ивуаре как сочиально-экономический конфликт между условно-автохтонным населением страны, укоренившимися мигрантами и мигрантами последних десятияетий. Методологической основой исследования является системный, структурнофункииональный, сравнительно-политический подходы, методы анализа, синтеза, индукиии, дедукиии, наблюдения. Конфликт в Республике Кот-д’Ивуар в 2010-2011 г2. можно рассматривать как между гражданами и не гражданами по поводу владения средствами производства, прежде всего, и по поводу гражданских прав, которые должны обеспечить равный доступ к экономическим ресурсам и ресурсам власти. Акцент в статье сделан на выяснении роли Франции в развязывании гражданской войны в Республике Кот-д’Ивуар в контексте политики «Франсафрик». Обоснован вывод о том, что Плтал республика инспирировала и долгое времл поддерживала ивуарийское противостояние с челью сохранения экономических и политических преференций Парижа в этом стратегически важном регионе.
\end{abstract}

Ключевые слова: вооруженный конфликт, автохтонное население, христиане, мусульмане, Алассан Уаттара, Аоран Куду Гбагбо, Республика Кот-д’Ивуар, Франция, безопасность, риски.

Abstract. Using the method of historical reconstruction, the authors show the latent causes of the armed conflict between the Muslim north and Christian south in the Republic of Côte d'Ivoire in 2010-2011. 


\section{КОНФАИКТОАОГИЯ / NOTA ВЕNE • 1 (6) • 2016}

A comprehensive analysis of a wide range of sources (media materials, judicial and journalistic investigations, evidence of well-known politicians and diplomats) can justify the view that describing this conflict as «ethnic» does not have sufficient grounds. Researchers propose to consider the situation in Côte d'Ivoire as a socio-economic conflict between the conditional-indigenous population of the country, rooted migrants and migrants decades as the conflict between citizens and non-citizens about the ownership of the means of production, in particular, and about civil rights, which should ensure equal access to economic resources and the resources of power. The methodological basis of this study includes the systemic, structural-functional, comparative-political approaches, the methods of analysis, synthesis, induction, deduction, observation. The accent of the article is made on clarifying the role of France in the outbreak of civil war in the Republic of Côte d'Ivoire in the context of the policy of «françafrique.» The conclusion that the Fifth Republic has inspired and has long supported the Ivorian opposition in order to maintain economic and political preferences of Paris in this strategically important region.

Key words: armedconflict, native peoples, Chrstians, Muslims, Alassane Ouattara, Laurent Gbagbo Kudu, Republic of Côte d'Ivoire, France, security, risks.

остав и Аемографическая структура насемения Республики Кот-А'Ивуар (общая численность, по Аанным на 2009 гоА, 21075 тыс. чемовек [1, с. 381]) крайне неоднородны. Жители страны говорят более чем на 50 языках. 3Аесь преАставлены три (в некоторых классификациях выделяют четыре) языковые подгруппы нигер-конгомезской группы нигеро-кордофанской языковой семьи. Крупнейшая из них - подгруппа $\kappa в a-$ преАставлена языками бете, бауле, аньи, гере, бакве, гребо и Ар., распространенными в месной зоне на юге страны. На языках подгруппы манде (малинке, диула, мано, квени, дан, бамбара и Ар.) говорят преимущественно в северных и северо-западных горных районах. Носители языков подгруппы гур (пмемена сенуфо, лоби, куланго, моси, бобо и Ар.) живут в саваннах и реАколесьях среАней части бассейна реки Бандама.

Соотношение социолингвистических групп в населении страны выглядит примерно так: носители языков ква составцяют $53 \%$, гур - $17 \%$, манде - $26 \%$, проч. $-4 \%$.

Хорошо известно, что в 60-е годы прошлого столетия границы новых независимых госуАарств были определены весьма произвольно и фактически воспроизвели границы заморских территорий колониальных держав. В результате близкие Аруг Аругу социокультурные (или социолингвистические) общности оказались разрезаны «по живому». Так, родственные по языку и происхожАению насемению Кот-А'Ивуара социолингвистические группы живут также в $\Lambda$ иерии (ква и манде), Гвинее (манде); в Мали и Буркина-Фасо (манде и гур); в Гане ква, манде и гур [2, с. 558-560]. Это обстоятельство, наряду с услов- ностью и прозрачностью межгосуАарственных границ, значительно упрощало миграционный обмен межАу странами региона.

По разным Аанным, от $30 \%$ до $50 \%$ населения Кот-А’Ивуар - иностранные гражАане, преимущественно из Буркина-Фасо и Мали, которые устраиваются по найму на сельскохозяйственные работы и зачастую остаются на территории Кот-А’Ивуара надомго. Gримерно 40 \% миграционного обмена страны составмяет Буркина-Фасо и $12 \%$ - Мали [3, с. 9]. В настоящее время мигранты составмяют примерно треть всех наемных рабочих страны.

Кроме того, в Абиджане проживают окомо 90 тыс. миванцев и сирийцев, а также 35 тыс. европейцев, в основном французов. По Аанным ООН, в Кот-А'Ивуаре в 1997 насчитывалось 220 тыс. беженцев из Аиберии. Часть из них интегрируется в местное общество, остальные при содействии ООН репатриируются на родину или переселяются в Сьерра- $\Lambda$ еоне.

Исторически сложилось так, что КотА'Ивуар стал перекрестком западноафриканских миграций. В половине миграционных потоков региона эта страна участвует и как принимающая, и как отАающая мигрантов. ОАнако это единственная страна в Западной Африке, которая принимает заметное количество мигрантов из Аругих стран не только этого региона, но и из Аругих африканских (и не только!) государств. Кроме того, это единственная страна в Западной Африке, которая имеет позитивное миграционное сальао.

Известные трения межАу аборигенным и пришлым населением имели место в КотА’Ивуаре еще в начале прошлого столетия. Так, 


\section{ВНУТРИПОАИТИЧЕСКИЕ КОНФАИКТЫ}

один из наиболее авторитетных французских ученых-африканистов Жан-Пьер Аозон отмечает, что противостояние автохтонов и иностранцев уходит своими корнями в колониальную эпоху. В частности, в 30-е годы прошлого столетия часть аборигенного населения (нарожАающаяся модернизированная элита) образовала Ассоциацию защиты автохтонов Кот-А’Ивуара (ADIACI), чтобы противостоять выходцам из Сенегала и Аагомеи (ныне - Бенин), занимавшим слишком большое место в колониальном управленческом аппарате [4, с. 50]. А в 1958 году, когАа КотА'Ивуар стал юридически автономным, многие сочли это поводОм Аля вЫАавливания Аагомейцев из колониальной аАминистрации.

В постколониальный периоА на протяжении Алительного времени у стран Западной Африки не было никакой продуманной и обоснованной миграционной политики. Хотя время от времени Буркина-Фасо и Мали пытались ограничить выезА своих гражАан, а Кот-А’Ивуар и Аиберия, напротив, - ограничить въезА. Правительства этих стран в 60-е годы прошлого столетия заключили ряА межгосударственных соглашений, но они не Аали заметных результатов. Так, еще в 1960 году Кот-А’Ивуар подписал «Конвенцию о рабочей силе» с Буркина-Фасо и в рамках этой конвенции узаконил следующие меры: установмение Авойного гражАанства (этот концепт был отклонен Аепутатами в 1963 году); Аоступ иностранцев к земельной собственности и к рабочим местам в государственном секторе; право голоса выходцам из государств Западной Африки на выборах в законодательные и исполнительные органы власти. В результате этих начинаний к 1965 году 17\% постоянного населения составцями иностранцы. Но в середине 60-х годов в ряде стран (в Буркина-Фасо, Бенине, Мали, Нигере, Того) произошии военные перевороты, что привело к охлаждению отношений Кот-А’Ивуара с этими странами. Это выразилось, в том числе, и в нескольких эпизодах высымок «буркинабе» (так называют выходцев из Буркина-Фасо) из страны. Аействие указанной «Конвенции ... » было приостановлено вплоть до середины 1970-х годов, когАа быиа предпринята попытка реанимировать ее действие, но в 1981 году в Буркина-Фасо произошел очередной переворот, и «Конвенция... » прекратила свое существование: новые власти Буркина-Фасо ввели ограничения на выезА [3, с. 16]. С тех пор миграционный обмен фактически никак не пманируется и не регулируется. Стоит отметить только, что в начаме 1990-х годов в
Буркина-Фасо снова меняется режим, и власть вновь начинает бкагоприятствовать эмиграции, полагая, что это будет способствовать миберамизации экономики и региональной интеграции. А в Кот-А'Ивуаре в это время к экономическому кризису добавился еще и кризис идентичности, выразившийся в нарастании ксенофобии и неприятия мигрантов.

И все-таки результаты переписей населений в Кот-А’Ивуаре показали, что миграция в этой стране интенсифицирова^ась на протяжении нескольких десятиметий. Аомя иностранцев в стране к 1988 году достигла 28\%, а в некоторых регионах месной зоны (Абуассо, Абенгуру) доля мигрантов была уже тогАа выше доли автохтонов. Население Абиджана к этому времени почти наполовину состояло из иностранцев, что делало из него скорее малийский или буркинийский гороА, чем столицу Кот-А'Ивуара [5, с. 543-557]. И в Аальнейшем, несмотря на ухудшение экономической ситуации, тенденция не изменилась: так, межАу переписями 1988 и 1998 годов численность мигрантов выросла с 1,8 до 2,1 млн человек.

Информация о конфессиональной принаАмежности жителей страны очень противоречива. По разным данным, от $23 \%$ до $40 \%$ жителей Кот-А'Ивуара исповедуют ислам, от 12\% до 25\% - христиане (гкавным образом - протестанты); верность традиционным религиям сохраняют от $11 \%$ до $65 \%$. Мусульманское население преоблаАает на северо-западе, к мусульманам относятся большинство говорящих на языках манде, и значительная часть говорящих на языках гур. Оплот христианства - юг страны, гАе в конце 19 в. появились первые христианские миссии. Христианство исповедуют, по большей части, группы, говорящие на языках кру и акан. Население АбиАжана почти поровну распределено межАу мусульманами и христианами. Число атеистов может достигать $17 \%$. Среди иммигрантов - 70\% мусульмане и $20 \%$ христиане.

Социолингвистическое и конфессиональное разнообразие населения страны придает известный колорит конфликтной ситуации в Кот-А'Ивуаре, оАнако интерпретировать его в терминах трайбализма или этничности было бы ошибкой, о чем будет сказано ниже. ПреАварительно ПривеАУ оАно суЖАение, которое поможет кучше понять суть происходящего сейчас в этой стране. «Происхождение с севера или с юга Кот-А'Ивуара, принадмежность к христианской или мусульманской общинам, к оАной из крупных этнолингвистических групп: месной 
зоны (коренные ивуарийцы) или западноафриканской саванны (северные ивуарийцы, превратившиеся в граждан второго сорта), а также к иностранцам из стран Сахемя (Буркина-Фасо и Мали), - все это сформировало Ава типа множественной идентичности, которые столкну-

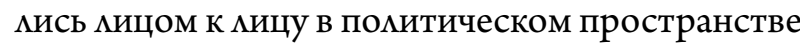
Кот-А'Ивуара, и столкновение межАу которыми угрожает внутреннему еАинству страны, а рикошетом и всему региону» $[3$, с. 16$]$.

\section{История конфмикта}

Независимость Кот-А’Ивуара (Берега Слоновой Кости) была провозглашена в августе 1960 года. На первых в истории этого государства выборах Президентом бым избран килер Аемократической партии Фекикс Уфуэ-Буаньи.

Бывшая метрополия - Франция - сохранима и сохраняет поныне симьные экономические и политические позиции в своей бывшей колонии. Сами французы констатируют тот факт, что страна занимала привилегированное место в системе отношений Франции с бывшими комониями, установившихся оАновременно с Пятой Респубцикой» (напомним, это 1958 гоА), а Ф. Буаньи играл ромь суперинтенданта (главного авторитетного кица - В.Ф.) франко-африканских отношений. В 1970-е годы все самые крупные преАприятия в стране были французскими, а коАичество французов в Кот-А’Ивуар Аостигало 50 тыс. человек (это в 5 раз больше, чем в 1960-м г. - году обретения независимости!) [6].

В сику благоприятной экономической конъюнктуры (наличия квалифицированных менеАжеров-французов, зарубежных инвестиций, дешевых рабочих рук и постоянного присутствия гастарбайтеров из сосеАних стран) темпы экономического роста Аостигали в 60-70 гоАы прошиого столетия 11\% в гоА. В 1979 гоАу КотА'Ивуар стам мировым мидером по производству какао-бобов и оАним из АиАеров по произвоАству кофе и какао. Но в 1980-е годы цены на эти товары на мировых рынках резко упали, что стало началом затяжной стагнации ивуарийской экономики. В Аовершение к этому в 1982-83 гоАах в регионе случилась засуха, за которой последовали резкий экономический спаА и кризис. Навязанная извне реструктуризация экономики привела к сокращению расходов на социальные нужаы и сокращению рабочих мест [7]. В конце 1980-х годов показатемь внешнего Аолга на Аушу насемения превысиц аналогичный показатемь всех стран Африки (кроме Нигерии). Как писам Ж.-П. Аозон, «ивуарийское чудо соответствует по своей глубине и Араматизму разразившемуся кризису» [6].

В новой ситуации присутствие значительного числа гастарбайтеров и укоренившихся мигрантов стало мощным конфмиктогенным фактором, Аеструктивно вмиявшим на формирование государственности Кот-А’Ивуара. В условиях экономического спаАа и растущей безработицы в аграрном секторе именно мигранты стали самой очевиАной «причиной» всех беА в обыденном сознании ивуарийцев.

Кроме того, госуаарство не бымо ни сплоченным, ни еАиным. Уже в гоАы правления Ф. Буаньи имели место вспышки межплеменной розни и преАпринимахись попытки сецессии. Так, в 1966 году внутри социолингвистического сообщества акан (именно его преАставители в это время находикось у власти) произошел раскол: родоплеменная элита аньи обвинила Президента страны в клановом протекционизме в пользу бауле (Ф. Буаньи по происхожАению - бауле) и потребовала права на выход из состава КотА'Ивуара и присоеАинения к Гане. (Именно на территории этой страны формировалось аканское языковое и культурное еАинство.) ОАнако эта попытка сецессии была жестоко подавлена (так называемый «Кризис Санви» - Sanwi [8].)

Несколько позже, в 1970 году против Аоминирования бауле восстали бете. («Кризис Гебие» - Guebie.) Аилер племенного сообщества бете - Крагбе Гнагбе, выходец из местечка Гебие, напрасно добивался конституционного права созАания оппозиционной партии. Ф. Буаньи ответил репрессиями, в результате которых были убиты, по разным Аанным, от 4 до 6 тыс. человек. Выжившие сопиеменники называют этот эпизоА геноциАом и Ао сих пор требуют репараций.

$Ф$. Буаньи открыто покровительствовац своей племенной группе и использовац все политические и финансовые ресурсы Аля превращения своей Аеревни Ямусукро в столицу государства. Этот период триумфа власти бауле (ики шире - группы аканских племен) остальные ивуарийцы называют периодом «аканите». Политическая Аоктрина «аканите» провозглашала, что именно аканцы преАназначены судьбой Амя управления госуаарством. Эта идеология формировака стойкие предубеждения в отношении Аругих пиеменных групп, относящихся к иным социолингвистическим сообществам. Так, преАставителей сообщества бете она представляла 


\section{ВНУТРИПОАИТИЧЕСКИЕ КОНФАИКТЫ}

как жестоких Аикарей, своего рода «индейцев Кот-А’Ивуара», не имеющих собственной помитической организации и не Аостойных того, чтобы находиться у власти. Что касается «северян» (выходцев из Мали, «буркинабе» и гвинейцев), то идеологи «аканите» объявляли, что они - «пришельцы», а значит, их удел - работа на плантациях ики в богатых Аомах «южан» в качестве прискуги. (Примечательно, что в этом бете были согласны с аканиами.) В отношении мигрантов и их потомков насаждались самые негативные ксенофобские предрассудки. Так, женщин из Ганы провозгласили проститутками (так называма их газета вмасти), а «буркинабэ» были объявлены ворами и преступниками. Иностранцы и их дети были мишены гражданства. Это объясняется тем, что эмиты «юга» боямись предоставлять избирательное права тем, кто мог бы проголосовать за кандидатов с «севера». (ОАной из причин попытки госуАарственного переворота 2002 года бымо то, что мимиионам этих мигрантов бымо возвращено избирательное право, и они проголосовали за северян.)

Трайбалистская рознь имела глубокие экономические и политические корни. По свидетельству африканских исследователей, в постколониальный период молодые независимые государства не смогли обеспечить своим гражАанам всю совокупность гражАанских, экономических и социальных прав: не хватило времени и ресурсов. Это в значительной степени подрывало гражАанскую идентичность и, фактически, нивелировало положение местного и пришлого населения. Как это ни парадоксамьно, но в условиях экономического спаАа мигранты априори обладали определенными преимуществами по сравнению с местным населением и стали своего рода «ферментами развития». Как правило, это зАоровые, инициативные, знающие несколько языков мюАи, которые, помимо всего прочего, вкАючены в межАународные сети солидарности. В отмичие от местных, которые в условиях кризиса выбираки стратегию выживания, мигранты, мобилизуя все свои экономические и символические ресурсы, стремились обеспечить себе социальную мобильность, улучшая положение своей семьи и общины. Они были заинтересованы в том, чтобы интегрироваться в принимающую среАу и готовы были Аля этого на смену языка, религии и образа жизни, но при этом они сохраняли то, что считали необхоАимым Аля поААержания «идентификационного равновесия». Автохтонное население болезненно ощущало утрату своих прежних имущественных и социамьных позиций. Фрустрация и неудовлетворенность мюАей стали причиной нарастания ксенофобии и страха переА «чужим».

Угроза масштабного социально-политического кризиса побудила Ф. Буаньи приступить к модернизации политической системы страны, мегализовать альтернативные правящей политические партии, инициировать демократический избирательный процесс. ИмиАж демократа-реформатора и многолетний опыт сохранения стабильности позволили этому популярному помитическому мидеру вновь побеАить на первых в истории страны многопартийных президентских выборах в 1990 году - он получил поААержку $81 \%$ избирателей. Свою роль сыграло и то обстоятельство, что Ф. Буаньи объявил: «Зем$\Lambda я$ принадлежит тем, кто ее обрабатывает!». И мигранты из стран Сахемя подАержали его; поскольку, именно они, зачастую, становились хозяевами земли. Все это имело Аалеко идущие послеАствия: нынешний конфмикт, по сути, своАится к попыткам автохтонов-южан вернуть себе главное среАство производства - землю [9].

Конкурентом Ф. Буаньи на этих выборах бым мидер Ивуарийского народного фронта Моран Гбагбо. ТогАа он проиграх выборы, но в дамьнейшем сыграц большую ромь в истории страны, и в настоящее время именно он персонифицирует оАну из сторон острой конфмиктной ситуации.

Моран Куду Гбагбо родился 31 мая 1945 года в Гагноа (департамент Мама) в бедной семье. В 1948 году его родители расстались, и мать воспитыввала детей одна. В 1958 году Аоран поступил в католическую семинарию, а в 1965 году окончил мицей в Абиджане и получил степень бакалавра фимософии. В 1969 году Абиджанский мицей выдал ему мицензию историка. В 1970 году Гбагбо женится на Симоне Эйве, истой католичке, и с этой поры христианство становится значимой составляющей его идеологического багажа. С 1970 года он работал преподавателем истории и географии в классическом мииее Абиджана. В этот период он активно участвует в профсоюзном движении и вливается в ряды нелегальной оппозиции. В результате нелегальной деятельности в марте 1971 года оказывается в военной тюрьме, в магере Буаке; заключение длилось по январь 1973 года. С 1974 года работает научным сотрудником в Абиджанском университете, в 1979 году зашишиает докторскую диссертацию в одном из филиалов Парижского университета. Тема диссертаиии «Социально-экономические пружины ивуарийской 
политики». (Ф. Гоми с горечью констатировам: «Самое отвратительное то, что именно интелмектуалы с университетским образованием ответственны за этот кризис» [10].) В 1980 году Гбагбо становитсл директором Института Истории в Абиджане, активно участвует в забастовочном движении профсоюза работников науки и выстего образования. В 1982 году он организовал нелегальную организацию, ставиую зародьием партии «Ивуарийский народныцй фронт». После разоблачения был вынужден покинуть страну и выехать во Францию. Переход страны $\kappa$ многопартийности становится главной политической идеей Гбагбо. В 1983 году он публикует в издательстве Арматан (l'Harmattan) работу, озаглавленную «Кот-д'Ивуар за демократическую альтернативу ». Во Франиии Гбагбо получает статус политического бежениа и сотрудничет с журнаıом «Аиберасьон Африк». При правительстве Ж. Ширака в 1986 году он стал объектом полищейских притеснений, имевших иелью вытеснить его обратно в Кот-д' Ивуар. Возвративиись в страну в сентлбре 1988 года, Гбагбо организует учредительный съезд Ивуарийского народного фронта, на котором избирается его генеральным секретарём, затем председателем партии ИНФ (оставался на этом посту до 2000 года).

После смерти Ф. Буаньи в 1993 году страну возглавия Анри Конан БеАье (также происходивший из бауле), задомго Ао этого провозглашенный политическим преемником скончавшегося первого президента страны. Аидер оппозиции $\Lambda$. Гбагбо назвац эту практику «монархическим наследованием» [8]. Уже в это время отчетливо обозначимись противоречия межАу условно-автохтонным населением и мигрантами, между мусульманами и христианами, между пиеменами «юга» и «севера». Противоречия эти, по сути социацьно-экономические, социально-политические и конфессиональные, все чаще приобретали трайбалистский оттенок. (Стихийные межпиеменные столкновения межАу условно «коренными жителями» региона и «пришлыми» гастарбайтерами имели место еще в колониальный периоА истории, в частности, в 1958 году, и позже - в 1969 и 1993 годах.)

В этом контексте уже в 1987 году была принята «Хартия ивуаризации», в соответствии с которой бым ограничен Аоступ иностранцев к земле, а в СМИ начамась кампания, обвиняющая иностранцев в нарушении безопасности в гороАской среАе.

Выше уже было сказано, что Аолго мидировавшие в помитическом пространстве бауле на-
хоАили ПоААержку в сообществе бете по мере того как противоречия межАу автохтонами юга и амлохтонами севера становимись все более явными. КонсомиАация сии южан потребовама изменения идеологической парадигмы: Аоктрина «аканите» уступима место концепции «ивуарийскости». В ответ на это зародилась иАеология северного национализма.

В политической практике это означало, что А. БеАье принял решение формировать свою клиентелу из числа «коренных» жителей южных регионов. В 1994 году он инициировал принятие нового «Избирательного кодекса , который мегитимизировац политическую Аоктрину «ивуарийскости». С этого времени правом выставить свою кандидатуру на президентских выборах пользовались кишь те, у кого оба родителя получили гражАанство Кот-А’Ивуара по рожАению, а не вслеАствие натурахизации.

Кроме того, была значительно усложнена процеАура натурахизации иностранных гражАан, фактически институализированы были преференции Аля коренных жителей страны при найме на работу. Несколько позже, в 1999 году, были подняты платежи за получение вида на жительство, на фоне общей коррупции выросли взятки государственных чиновников за натурамизацию.

Следует отметить, что в постколониальный период в Западной Африке сохранялось общее Аля многих стран франкофонное культурное пространство. Несмотря на то, что преАставители многих социолингвистических групп проживают в разных странах, а в каждой стране проживает пестрый конгломерат племенных общностей, принаАлежащих к разным социолингвистическим группам, практически все бывшие французские колонии попытались превратить новые государства в национальные государства по французскому образиу. Французский язык быи установлен как государственный язык и язык образования. Соответственно системы государственного управмения, образования, зАравоохранения были скопированы с французского образца. Помитика молодых государств была направлена на устранение этнолингвистических и религиозных иАентичностей и формирование общенационамьных гражАанских идентичностей. Это способствовамо развитию плюрилингвизма (абсолютное большинство насемения этих стран говорит как минимум на Авух языках) и формированию реального мумьтикультурализма. ПослеАний трактовался и как илеология, и как практика, выражающаяся в толерантном отношении к происхожАению, язы- 


\section{ВНУТРИПОАИТИЧЕСКИЕ КОНФАИКТЫ}

ку и рекигии согражАан и эмигрантов. Повышенная концентрация в регионе мигрантов, облаАающих множественной идентичностью, весьма способствовала распространению илеологии мультикультурализма [3, с.12].

Оформление концепции «ивуарийскости» в сереАине 1990-х годов в основной принимающей стране региона стало признаком глубокого изменения в понимании идентичности. Ао 1990 года гражАанство не имело никакого значения. Кот-А'Ивуар конструировался как государство алмохтонов. Ааже в школьных учебниках проводилась мысль о том, что почти все гражАане страны раньше или позже пришии сюда из сосеАних стран, «коренное» же население составляет незначительное меньшинство. С изобретением концепта «ивуарийскости» все перевернулось с ног на голову [11]. Многие авторы отмечают, что положение иностранцев не только в КотА'Ивуаре, но и во всей ЗапаАной Африке стало ухудшаться [12, с. 81-93]. Эмизабет Аннан-Йао, в частности, пишет: «Экономический кризис в Кот-А'Ивуаре привел к стигматизации мигрантов со стороны государства, но еще в большей степени - со стороны коренного населения. Последнее ощущает, что наводнившие страну мигранты угрожают их безопасности, созАают конкуренцию на рынке труаа, в Аоступе к земельным и пищевым ресурсам $\gg$ [5, с. 543-557].

Парадигматическая фигура «ивуарийскости» происходит из этнонационализма бауле (идею верховенства бауле часто называют «аканите»). При поААержке ареопага интемлектуалов и писателей А. Бедье выАвинум Ава аргумента, которые Аолжны были стать концептуальным обоснованием этой идеи и превращением ее в политическую Аоктрину. Во-первых, было заявлено, что траАиции госуАарственности Акана были Аостаточно богаты Аля того, чтобы поскужить Авижущей симой модернизации страны (наподобие того, как «азиатские Араконы» смогли Аостичь процветания, опираясь на аутентичное культурное наследие). Во-вторых, настойчиво пропагандировалась идея, согласно которой кумьтура бауле Аолжна быть положена в основу государственности, поскольку она преАставляет собой гармоничное равновесие межАу мюАьми власти и земии, межАу аристократией и плебсом $[4$, с. 50].

Сами африканские авторы отмечают, что государство в Кот-А’Ивуар никогаа не было ни нейтрахьным, ни Аемократическим. Ни оАин из президентов страны ни разу не был избран Аемократическим путем. Государство всегда пра- ктиковало в разной форме социокультурную («этническую») Аискриминацию и потому воспринимахось группами, отстраненными от власти, как государство одной группы («этноса»). Таким образом, Аля отАемьных групп населения госуаарство всегАа преАставляло собой угрозу. В этом контексте Аискуссия об «ивуарийскости» преАставцяет собой Аишь ОАин из эПизодов Аоминирования эмит юга страны.

Аля А. БеАье «ивуарийскость» была козырем Аля обоснования его особой мегитимности. Реализация этой шовинистической по сути Аоктрины в политической практике позволили ему получить голоса коренных ивуарийцев на выбоpax 1995 года. Заметим, эти выборы бойкотировала оппозиция.

Разумеется, политическая практика такого рода могла мишь расколоть страну, но никак не способствовала ее умиротворению. Но, несмотря на этот очевидный факт, концепт «ивуарийскости» начам активно внеАряться в политический Аискурс и в массовое сознание, что вызвало нарастание волны ксенофобии и межплеменной розни. Начались погромы и избиения мигрантов. В 1998 году из страны были высланы 800 малийских рыбаков. В Аекабре того же года был принят закон, ограничивающий право иностранцев на владение землей, а в ноябре 1999 года из региона Табу были высланы 20 тыс. «буркинабе».

В то же время статистические исслеАования, проведенные в конце 1990-хгодов в Кот-д’Ивуаре, показами, что эмигранты были затронуты безработицей в меньшей степени, чем местное насемение, а также зафиксировали высокий уровень интеграции мигрантов в местные сообщества. Выяснилось, что мигранты мучше устраивались благодаря своим сетям подАержки (как правило, родопиеменным), при этом эффективность этих сетей подАержки не была связана напрямую с численностью соответствующих этнолингвистических групп. Например, в Кот-А'Ивуаре самый низкий уровень безработицы отмечался в это время у сену ны, а остальные - выходцами из Буркина-Фасо и Мали [13, с. 251-269].

ОАнако справеАливо и Аругое. В 1998 году из 4,0 млн. иностранцев, зафиксированных переписью населения, только 2,2 млн. были мигрантами, а 1,8 мин. (то есть $10 \%$ населения) родимись в Кот А’Ивуаре и жили в этой стране постоянно. ОчевиАно, что с процеАурой натурахизации чтото не в порядке. Как в сложившейся ситуации быть второму и третьему покомению ивуарий- 
цев, преАки которых пересемились сюда из Сахемя? Требовать гражданства в странах исхода своих преАков и потом просить виА на жительство в Кот-А’Ивуаре? Но большинство из них не имеет возможности поАтверАить свое роАство в странах исхода вследствие несогласованности работы государственных служб, а также собственной неграмотности и отсутствия официальной регистрации браков [3, с. 19]. В резумьтате они не могли претендовать ни на гражАанство Кот-А'Ивуара, ни на гражАанство страны исхода родителей. Так называемый процесс идентификации Аолжен бым подтверАить право мигрантов на гражАанство Кот-А'Ивуар, но в ходе этой процеАуры примерно четверть населения страны не смогма поАтверАить это свое право [11].

В этих условиях неизбежной стала институализация конфликта. В конце 1990-х годов у А. БеАье появился серьёзный политический конкурент - Алассан Уаттара, который персонифицировал политические устремления мусумьманского Севера страны и большинства укоренившихся мигрантов, преимущественно выходцев из Буркина-Фасо и Маци.

Аласса $\bigotimes_{\boldsymbol{н}}$ Арама $\bigotimes_{\boldsymbol{н}}$ Уатmара варя в Аимбокро, на территории Кот-д’Ивуара, хотя политические оппоненты утверждают, что он родился в Буркина-Фасо. Окончил Университет Арекселя и Университет Пенсильвании. Работал в Международном Валютном Фонде (в 1984-88 годах возглавлял Африканский департамент МВФ) и Центральном банке государств Западной Африки (в 1988-90 возглавлял его). В 1990 году президент Кот-д’Ивуара Феликс Уфуэ-Буаньи назначил его руководителем межминистерского ведомства по стабилизации и развитию экономики, а затем в ноябре того же года он был назначен премьер-министром. 9 декабря 1993 года, через два дня после смерти Уфуэ-Буаньи, Уаттара покинул пост премьер-министра. В 1994-99 годах работал в МВФ в должности заместителя директора-распорядителя. Перед президентскими выборами 1995 года оппозиционная партия «Объединение респубиканцев н намеревалась выставить его в качестве единого кандидата, однако Уаттара впоследствии отказался от участия в выборах. 1 августа 1999 года был избран руководителем «Объединения республиканцев» (РАP).

Важно отметить, что сам он родился на территории Кот-А’Ивуара, однако его родители были выходцами из Буркина Фасо, хотя и получившими ивуарийское гражАанство. Этот факт изначацьно ставих мегитимность участия А. Уат- тары в электорамьном процессе поА сомнение и был чреват конфмиктами.

24 декабря 1999 года группа военных, возмущенных отказом Правительства выпиатить Аеньги участникам миротворческой операции в Центральноафриканской Республике, инициировала массовые беспорядки в столице, закончившиеся отстранением А. БеАье от Аолжности. (ПослеАний укрылся во французском посольстве, а впоследствии бежац в Того.) В результате военного переворота во главе страны оказался начацьник штаба армии генерах Роббер Гуэ. (Он происхоАил с запаАа страны и принаялежал к социолингвистической общности манде.) Важно отметить, что в результате этого события и последующих катаклизмов в Кот-А’Ивуаре впервые оказался выходец не из бауме, что, как отметил Ж.-П. Аозон, «положило конец этницистской версии ивуарийскости» [4, с. 53]. Примечательно, что сразупосле прихода к власти, генерах начац очищать от бауле государственный аппарат и армию. Напомним, президент Ф. Буаньи неизменно ставил во главе армии особо приближенных к нему мюАей из своей семьи ими пиеменной группы. И его приемник А. БеАье продолжия эту традицию. Сразу после военного переворота Гуэ провел в армии чистку, в результате которой часть генералов и офицеров бежами в Буркина-Фасо. СреАи сбежавших был Ибрагим Кулибали - один из организаторов и активных участников восстания 2002 года.

Конфмиктная ситуация приобрела вскоре оттенок межконфессиональной розни: столкновения сопровожАались нападениями на церкви и мечети. Как полагают французские исследователи, в этом проявияась боязнь христиан юга оказаться поА властью А. Уаттары и его союзников-мусумьман, которые к этому времени уже занимаци веАущие экономические позиции в стране [12, с. 81-93].

Правление Р. Гуэ было неАолгим. В 2000 гоАу, стремясь приАать своей власти виАимость мегитимности, он провем всеобщие выборы. Выборы эти, по мнению экспертов, ознаменованные подтасовками и массовыми беспорядками, неожиАанно закончились побеАой оппозиции. Официально победителем выборов бым признан оАин из ее мидеров - $\Lambda$. Гбагбо. (В ходе выборов были Аисквамифицированы Ава преАставителя оппозиции: экс-президент А. БеАье и мидер «северных А. Уаттара. В результате еАинственным кандиАатом от оппозиции оказался $\Lambda$. Гбагбо.) Многие исследователи полагают, что концепт «ивуарийскости» и «Аиульская угроза» были 


\section{ВНУТРИПОАИТИЧЕСКИЕ КОНФАИКТЫ}

мобилизованы именно амя того, чтобы преграАить Аорогу А. Уаттаре [10].

Пытаясь сохранить власть, Р. Гуэ объявиц себя победителем, хотя по официальным итогам выборов мидировац $\Lambda$. Гбагбо (59,4\% против $32,7 \%)$. В ответ послеАний призвал членов ФПИ к акциям неповиновения. Элитные правительственные подразделения сил безопасности расстремяли демонстрацию оппозиции. Фактически это стало началом гражАанской войны. Армия в уличных столкновениях участия не принимала. Р. Гуэ опирался на жандармерию, полицию, вооруженную клановую клиентелу и боевиков, пере-

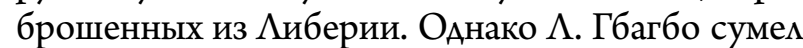
мобилизовать «улицу». В массовых акциях протеста принимали участие столь внушительные силы, что генерал счел за благо бежать в Бенин. Во главе Кот-д’Ивуара оказался $\Lambda$. Гбагбо.

Но это не стало поводом амя умиротворения страны. На улицы столицы вышли сторонники А. Уаттары, требовавшие переголосования с участием своего милера, незаконно, по их мнению, отстраненного от участия в выборах.

По всей стране начались массовые столкновения, участники которых пользовались битыми бутылками, камнями, палками, железными прутьями и огнестрельным оружием. Верные $\Lambda$. Гбагбе симовые структуры с избыточной жестокостью поАавили массовые выступления «северян». Участников акций протеста оппозиции расстреливали на месте, тела погибших в спешке быми захоронены в братских могилах ими просто брошены в воды Гвинейского Залива. Сведения о числе жертв весьма противоречивы: итоговая цифра убитых, по правительственным Аанным, - 164 в одном только Абиджане; ИНФ объявии о 60 погибших своих сторонниках, РАР - о 155 (правАа, по всей стране), авторитетный международный справочник называет цифру 150 погибших [14].

Сразу после вступления в Аолжность $\Lambda$. Гбагбо начал агрессивную пропагандистскую кампанию, направценную против «северян» и мигрантов, насажАая мифы о «засилье пришлого насемения» и «оккупации земель истинных ивуарийцев».

Используя массовое недовольство «северян», Р. Гуэ организовац 19 сентября 2002 года военный мятеж в Абиджане. Мятеж бы подавмен, а сам Р. Гуэ убит. При этом его сторонники, консолидированные в «Авижение за справеАливость и мир», установили практически полный контроль наА территориями на северо-западе страны. Северная ее часть была занята «Патрио- тическими силами Кот-А-Ивуара» Гийома Соро, мояльного А. Уаттаре. ПоА контролем правительства $\Lambda$. Гбагбо осталась Аишь южная половина государства. 2 декабря вспыхнули ожесточенные бои между войсками, подконтрольными Гбагбе, и повстанцами в пригородах города Мэн на западе страны (28 ноября он быи захвачен боевиками из «Авижения за справеАливость и мир»).

Это стало началом затяжной гражАанской войны межАу политическими группировками «Севера» и «Юга». Основной повстанческой группировкой северян, пользовавшихся поддержкой правительств Буркина-Фасо и Аиберии, были «Патриотические симы Кот-д’Ивуара» во главе с Г. Соро. На стороне $\Lambda$. Гбагбы тога выступияа Франция, которая поА предлогом защиты многочисленного европейского населения страны оказала ему подАержку своими вооруженными силами («операция Аикорн»). Кроме того, в Кот-А’Ивуар быми направлены регумярные войска из Нигерии.

ЗАесь важно отметить следующее. ЕАва придя к власти, $\Lambda$. Гбагбо (как и его преАшественники) начал «этническую» чистку в армии. Из силовых структур выдавливались, прежде всего, «северяне» из группы манде, которые Аоминировали в армии во время правления Р. Гуэ. ОАновременно была распущена их «Молодая гвардия» (ее чиены были обвинены в заговоре). ОАновременно $\Lambda$. Гбагбо рекрутировац своих соплеменников бете в полицию и жандармерию. В результате этих манипумяций начались распри межАу разными силовыми структурами, поскольку Аля усмирения армии $\Lambda$. Гбагбо использовац жандармерию. В армии назревало серьезное недовольство, которое президент был не в состоянии погасить. Его клиентела из числа бете слишком малочисленна и обладает слишком малыми экономическими и политическими ресурсами аля того, чтобы противостоять бунтующим военным. Поэтому $\Lambda$. Гбагбо в начаме своего правления был вынужден опираться на подАержку французской армии, а также искать военную помощь со стороны Анголы.

Кроме того, $\Lambda$. Гбагбо изначально был недостаточно мегитимен и не очень популярен, так как слишком явно монополизировац власть в интересах своего кцана. Это возмутило аканцев, которые в свое время формулировали доктрину «ивуарите», но которых он начал столь явно оттеснять от власти.

Кровавые столкновения продолжались Ао 2003 года, когАа межАУ официальными властя- 


\section{КОНФАИКТОАОГИЯ / NOTA BENE • 1 (6) • 2016}

ми и повстанцами было Аостигнуто согмашение о прекращении боевых Аействий. «Соглашение \инас-Маркуссис» предусматривало созАание коалиционного кабинета из 41 портфеля. «Юг» и «Север» быми преАставлены в нем практически поровну, а во главе его оказался «северянин» Сейду Аиарре, креатура Парижа [15]. Правительство это не могло собраться Ао апремя, а уже в декабре оппозиция объявияа о своем отказе от соблюдения условий договора. Произошио это после осады французских гарнизонов: толпа требовама вывести войска бывшей метрополии с территории страны.

В ноябре 2003 года в провинции Гагноа вновь начались столкновения межАу племенем бете и гастарбайтерами из Аиберии и БуркинаФасо: в результате вооруженных столкновений там погибли 9 человек. Все погибшие принаАлежами к общности бете.

25 марта 2004 года Правительство силой разогнало Аемонстрацию оппозиционеров, в столкновениях погибли 2 силовика и 120 Аемонстрантов (по правительственным Аанным, 37 погибших). По информации независимых экспертов, причиной этих столкновений стац спор о том, «кому кормиться с порта». В результате этих кровавых столкновений кабинет распался: оппозиционеры вышии из правительства, и конфликт вступим в новую стаАию. Стадия эта характеризуется, в частности, использованием тяжелых вооружений и авиации. С июня по октябрь 2004 года правительственная авиация нанесла несколько уАаров по позициям повстанцев к северу от минии прекращения огня. По некоторым Аанным, в операциях принимахи участие беморусские и украинские наемники.

Своего апогея эта стадия достигма 6 ноября, когАа Ава правительственных штурмовика Су-25 атаковали военную базу миротворцев, размещенную близ Буаке; в результате этого налета погибли 9 военнослужащих из миротворческих сил. (Примечательно, что $\Lambda$. Гбагбо при этом заявил: «Трупов я не виАел и не знаю, правАа ми они погибли? ». Он обосновац жестокость своей клиентелы необходимостью борьбы с неоколониализмом [16].)

Штурмовики, принимавшие участие в атаке, вскоре были уничтожены французской авиацией прямо на аэродроме. Это стало поводом Аля массовых беспоряАков в АбиАжане. Аидеры ИНФ, используя неформальные клиентелистские и трайбалистские связи, собрали многочисленные толпы своих сторонников (преАставителей пиемен, относящихся к социолингвистическому сообществу кру - бете, бакве, гребо и Ар.). ОтряАЫ боевиков ПоА ПреАвоАитемьством близких $\Lambda$. Гбагбо партийных функционеров разгромики офисы оппозиционных партий и газет и преАприняли попытку при поААержке правительственной армии атаковать базу французского батацьона морской пехоты. Французские военные не только отразили нападение, но и взяли штурмом аэропорт и уничтожили все находившиеся там самолеты. Французы разогнали толпы мародеров, которые начали грабить кварталы, населенные в основном мусумьманами, выходцами с Севера - преАставителями племенных групп диула, малинке, мано, дан. (В правительственной сводке По этому поводу значимось, что «негоАяи-комонизаторы» убили 64 человека и раними 1,5 тыс. мирных горожан.)

Ночью французская авиация нанесла удары по мостам через магуны, разделяющие разные кварталы города, а утром французские миротворцы приступили к эвакуации соотечественников и иных европейцев, которые подвергались насимию (многие школы и магазины французов были разграблены и сожжены, иностранцев избиваки и насиловаци, однако никто из них не был убит, что, по мнению авторитетных анамитиков, свидетельствует о том, что эти аКции прохоАили ПоА контролем и преследовали вполне определенные цели) [14]. В результате этих кровавых столкновений 8 тыс. проживавших в Кот-А'Ивуаре французов были вынужАены покинуть страну.

ОАновременно в семьской местности на северо-запале страны грабими и убивали преАставителей племени диула и гастарбайтеров из сосеАних государств. Противостоять погромщикам было некому, поскольку миротворческие силы в это время были переброшены на юг.

Напряженность начала спаАать только к концу 2004 года. Экономическое положение в стране становилось все хуже, а подАержка $\Lambda$. Гбагбо со стороны сопиеменников - бете и роАственных им племенных групп из социомингвистических общностей кру и акан все менее явной. Бегство гастарбайтеров из Маки, Буркина-Фасо, Аиберии и Аругих стран усугубило и без того скверное экономическое положение Кот А’Ивуара. В то же время Аипломатическое Аавление со стороны сопреАельных государств все более нарастало.

В сложившейся ситуации $\Lambda$. Гбагбо в декабре 2004 года счел за благо заключить перемирие. Начались затяжные переговоры, продолжавшиеся более Авух мет, пока, наконец, в марте 2007 года в результате переговоров, проходивших в УагаАу- 


\section{ВНУТРИПОАИТИЧЕСКИЕ КОНФАИКТЫ}

$г у, \Lambda$. Гбагбо не подписал указ о назначении главы оппозиционеров Г. Соро премьер-министром и не согласился на все ранее выставленные условия. Вероятно, обе стороны пришли к заключению, что ситуация может развиваться в интересах третьих сил, и мидеры «Севера» и «Юга» посчита$\Lambda$ и нужным пойти на тактическое перемирие.

25 июмя 2007 года $\Lambda$. Гбагбо впервые за пять мет прибыл на север страны и в совместном с Г. Соро выступлении на стадионе в Буаке провозгласил завершение гражАанской войны. В результате этой войны с 2002 по 2005 гоА погибли около 3 тыс. человек.

\section{Выборы 2010 года}

Несмотря на то, что всеобщие выборы в стране были оАним из пунктов Аостигнутого в 2007 году мирного согмашения, $\Lambda$. Гбагбо, тем не менее, вПлоть Ао 2010 года затягивал начало электорамьной кампании. Выборы главы госуАарства Аолжны быми пройти пять мет назаА, оАнако переносимись более семи раз из-за разногласий межАу $\Lambda$. Гбагбо и оппозицией по поводу списка избиратекей.

Назначенные на ноябрь 2010 года выборы были призваны стать символом полного примирения преАставмявших мусульманский «Север» и христианский «Юг» страны политических группировок. ОАнако их результаты не только не стабимизировали ситуацию в Кот-А’Ивуаре, но и вновь поставили страну на грань гражАанской войны.

По информации Избирательной комиссии, во втором туре состоявшихся в ноябре 2010 года выборов А. Уаттара набрал 54,1\% голосов, а его

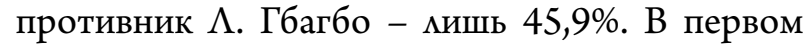
туре голосования они набрали $32,08 \%$ и $38,3 \%$ соответственно [17]. В своем северном регионе А. Уаттара побеАим соперника с очень хорошим счетом (за него голосовали все мусульмане и $\partial u$ $y \wedge a), \Lambda$. Гбагбо одержал победу в западных регионах и некоторых квартацах АбиАжана (прежАе всего, среди своих соплеменников бете) [10].

Но Конституционный совет республики (высший орган Кот-А’Ивуара) объявиц, что итоги голосования в некоторых областях страны были сфальсифицированы, и не признал результаты выборов в семи северных департаментах. ПоАавмяющее большинство жителей этих департаментов подАерживают А. Уаттару. (Около покумимлиона голосов сторонников оппозиционера быми признаны недействительным.)

4 декабря и $\Lambda$. Гбагбо, и А. Уаттара объявили о своей побеАе, принесли присягу и вступили в
Аолжность Президента страны. Оба незамедиительно назначили свои кабинеты министров.

Опираясь на решение Конституционного совета Кот-А’Ивуара, $\Lambda$. Гбагбо продолжац контролировать государственный аппарат, включая армию и полицию, которые были вывеАены на умицы в ответ на призыв сторонников А. Уаттары захватить здания правительственных учрежАений. Помимо собственных симовых структур, $\Lambda$. Гбагбо пользовался Аля удержания власти вооруженной подАержкой наемников из Аиберии и своей кмановой клиентелы.

16 декабря сторонники А. Уаттары преАприняли попытку захватить государственное телевидение и вынудить власти признать мидера оппозиции новым президентом страны. Силы безопасности открыми огонь по сторонникам оппозиции, в результате чего погибло не менее 20 человек.

В ответ на попытки $\Lambda$. Гбагбо разрешить конфмикт силовыми методами бывший командир повстанцев, а ныне глава кабинета министров Г. Соро призвал межаународное сообщество применить сику, чтобы «свергнуть Аиктатора».

В первые Ани декабря накал страстей вылился в массовые волнения во многих городах КотА'Ивуара, в том числе и на улицах крупнейшего города страны АбиАжана. Пытаясь остановить народное волнение, $\Lambda$. Гбагбо приказал прекратить вещание в стране иностранных телеканалов и закрыть морские, сухопутные и водные границы.

По Аанным ООН, к концу 2010 года, в результате столкновений межАу сторонниками и противниками президента $\Lambda$. Гбагбо погибли 173 человека. Поскольку экспертов ООН не пустили на место преАположительного массового захоронения, можно преАположить, что реальное число жертв может быть еще выше.

На фоне этих событий Агентство по декам беженцев ООН заявило, что 14 тыс. человек уже перешии границу Кот-А 'Ивуара и Аиберии, опасаясь, что нестабильность в стране приведет к насилию, жертвами которого станет мирное население. По словам преАставителей ООН, большинство беженцев - женщины и дети, причем в большинстве своем это сторонники А. Уаттары. Уже 31 декабря число беженцев достигло 15 тыс. человек [18].

30 Аекабря Юсуф Бамба, назначенный А. Уаттарой преАставителем Кот-А 'Ивуара при $\mathrm{OOH}$, заявик, что страна стоит на грани геноциАа. Он добавил, что «некоторые дома в разных населенных пунктах помечены символами, относящимися к племенным корням их житекей, и его очень беспокоит то, что может за этим по- 
следовать» [19]. Таким образом, можно преАпомагать, что сторонники $\Lambda$. Гбагбо готовятся к массовым репрессиям по отношению к своим противникам - вероятнее всего, представителям «северных» пиеменных общностей - прежАе всего, диула, малинке, сенуфо и Ар.

Вполне возможно, что жертвами могут стать жители мусумьманских кварталов Абиджана. (Известно, что в АбиАжане жители группируются по принципу общности происхожАения, и отАельные кварталы населены целиком сторонниками $\Lambda$. Гбагбе и А. Уаттары. Поэтому в городе очень мегко спровоцировать резню [9].)

Аело в том, что $\Lambda$. Гбагбо - ревностный христианин. Безусловно, протестантская церковь, несмотря на миролюбивую риторику, матентно подАерживает именно его, как выразителя интересов христианского «юга». Российский пастор из Уссурийска пишет на церковном сайте о том, что его Аруг пастор Ажон Сангер на протяжении многих мет посещал Кот-А Ивуар и «имел честь беседовать и молиться вместе с президентом

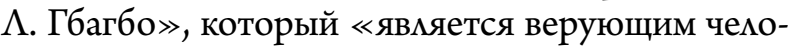
веком и поэтому постоянно поАвергается напаАкам со стороны мусумьманской части насемения».

По сведениям этого церковного деятеля, «в северной части страны, гАе большинство состав яют мусумьмане, мюАи, собирающиеся голосовать за $\Lambda$. Гбагбо, подвергаются насимию, вплоть Ао убийств. НаблюАаются массовые фамьсификации. Нескомько сторонников презиАента $\Lambda$. Гбагбо быми убиты, а женщины изнасимованы $\gg[20]$.

На роль посреАника в конфмикте претенАует католическая церковь. Известно, что 21 Аекабря 2010 года правящий архиепископ АбиАжана Жан-Пьер Кутва созвац экстренное совещание, на которое пригласим не только политиков из разных магерей, но и исламских религиозных миАеров. «Нам всем хочется мира в стране», - заявиц архиепископ и призвац собравшихся сАелать все возможное Аля преАотвращения кровопромития. ГАавная задача, по мнению католического иерарха, закмючается в том, чтобы противостоять попыткам некоторых политических сил сАелать конфликт религиозным. Вместе с главой Высшего совета имамов Кот-А'Ивуара - шейхом Бойкари Фофана - архиепископ Ж.-П. Кутва призвац не Аопускать провокаций на религиозной почве. По Аанным радио Ватикана, тысячи мюАей покиАают свои Аома и ищут убежища в католических храмах и миссионерских центрах как на юге, так и на севере страны.

\section{Позиция мирового сообщества}

Мировое сообщество всерьез озаботилось угрозой возобновления в Кот-А'Ивуаре гражАанской войны и утраты своих позиций в этом стратегически важном регионе. 3 декабря США, Франция и Великобритания признали победу А. Уаттары, заявили о необходимости уважать волю народа Кот-А'Ивуара и призвами $\Lambda$. Гбагбо уйти со своего поста [21].

С подобными заявлениями выступики верховный преАставитемь ЕС по иностранным Аемам и политике безопасности Кэтрин Эштон и генерамьный секретарь ООН Пан Ги Мун. Всемирный банк и Африканский банк развития заявики о возможном прекращении финансовой подАержки Кот-А'Ивуара, а руководство Экономического сообщества стран ЗапаАной Африки приостановико чиенство этой страны в организации. Позже Африканский союз, а затем генсек и Совбез ООН признали мегитимность избрания А. Уаттары. Несколько позже, 7 Аекабря, презилент США Барак Обама пригрозил $\Lambda$. Гбагбе санкциями.

8 Аекабря 2010 года, накануне обсуждения заявления о ситуации в Кот-А’Ивуаре, члены Совбеза ООН заслушали по видеосвязи Аетальный АоклаА гмавы миссии ООН в этой стране Чхве Ен Ажина. ПослеАний обосновал признание побеАы на президентских выборах в Кот-А'Ивуаре кандидата от оппозиции, экспремьера страны Уаттары. «Ааже если принять во внимание количество жалоб, направленных в Конституционный совет сторонниками Аействующего президента, результаты второго раунаа выборов все равно останутся неизменными»,- отметим он.

Выступление главы миссии ООН в КотА’Ивуаре, казалось бы, убедимо членов Совбеза в необходимости признания победы оппозиционного кандидата. По крайней мере, в этом заверяла журналистов постпреА США при ООН Сьюзан Райс. ОАнако итоги голосования стали Аля нее большой неожиданностью. После более чем пятичасового обсужАения итогов выборов в Кот-А’Ивуаре выводы Чхве Ен Ажина подАержами 14 из 15 стран-чменов Совбеза ООН. Против выступила только Российская Фелерация. «Это странная ситуация. Я не знаю, почему Россия неАовольна резолюциями, за которые сама голосовала», - выразила свое уаивление Сьюзан Райс [22, с. 4]. Отметим, что несколько позже Россия присоединилась к резолюции Совбеза ООН. 


\section{ВНУТРИПОАИТИЧЕСКИЕ КОНФАИКТЫ}

10 декабря Соединенные Штаты призвали $\Lambda$. Гбагбо уважать результаты выборов и мирно передать власть своему преемнику. Как заявика госсекретарь США Химлари Клинтон, «презиАент Обама вовлечен в это дело персонально» и Ааже «отправия президенту $\Lambda$. Гбагбо письмо, в котором призвац его уступить (пост президента) и преАупреАил о том, что его ЖАут ПослеАствия, если он этого не сделает $\gg$.

14 декабря начались столкновения межАу вооруженными силами страны и боевиками, подАерживавшими А. Уаттару. Перестрелка произошла возме гостиницы, гАе разместилась штаб-квартира оппозиции. Мировое сообщество, в том числе США, Франция, ООН и Африканский союз, выдвинули ультиматум $\Lambda$. Гбагбо, призвав его уступить власть А. Уаттаре. 17 Аекабря Евросоюз призвал ивуарийскую армию перейти поА командование А. Уаттары; тогаа же Николя Саркози пригрозик $\Lambda$. Гбагбо санкциями Евросоюза. 20 Аекабря эти санкции последовали - Аипломатические преАставители 27 стран Евросоюза на встрече в Брюсселе одобрили введение запрета на въезА в Европейский союз Аля $\Lambda$. Гбагбо и 18 миц из его окружения. (БриАжит Кюйо, преАставитель партии $\Lambda$. Гбагбо, заявика на это в Париже: «Я спрашиваю, зачем нужна эта история с визами. Кому нужно изолировать Кот-д'Ивуар и его президента. Знают ми европейские руководители, что Конституционный Совет призная $\Lambda$. Гбагбо победите$\Lambda е м ? \gg[23]$.$) Евросоюз ввел и экономические$ санкции против правительства $\Lambda$. Гбагбо.

Кроме того, $\Lambda$. Гбагбо подвергся санкциям со стороны финансовых организаций. В частности, 22 декабря Всемирный банк заявия о приостановке финансовой помощи Кот-А'Ивуару, а 23 декабря Центральный Банк экономического и валютного союза западноафриканских госуАарств заблокировац счета $\Lambda$. Гбагбо.

3Аесь надо отметить, что сопредельные африканские государства вынуждены вести себя достаточно сдержанно. Выходцы из этих стран живут в Кот-А'Ивуаре, и если по отношению к этой стране будут приняты жесткие меры, это неизбежно спровоцирует гражАанскую войну и избиение соответствующих Аиаспорных групп, в частности, на юге Кот-А'Ивуара, гАе на пмантациях какао живут 5 млн. выходцев из африканских стран южнее Сахары. Если ситуация выйдет из поА контроля, то они подвергнутся нападению. Особенно угрожающим явмяется положение выходцев из Сенегама и Нигерии [9].
22 декабря французские власти призвали своих согражАан покинуть Кот-А'Ивуар. ПреАставитель французского правительства Франсуа Баруан назвал рекомендацию превентивной мерой по защите 15 тыс. французов, находящихся сейчас в этой стране. С аналогичным призывом к своим гражАанам обратилась и Германия.

В ответ на реакцию Запада $\Lambda$. Гбагбо выступил с разоблачениями в аАрес Франции и США, которые якобы организовали заговор с целью отстранить его от власти, и высказался за немеАменный вывоА миссии ООН из Кот-А’Ивуара. Выступая по национальному телевидению, он заявия, что находящийся в Кот-А’Ивуаре миротворческий контингент, а также французские подразделения, Аолжны покинуть территорию страны, поскольку «они завершили свою миссию», а «если они не сАелают этого, то будут рассматриваться как мятежники». В то же время он ПреАложия создать меЖАуНародную комиссию Амя «объективного анализа» итогов ноябрьских выборов главы государства, спор изза которых вызвал в стране острейший кризис и волну насилия, привеАшую к большому числу жертв. По словам $\Lambda$. Гбагбо, в состав такой комиссии могли бы войти преАставители Экономического сообщества стран Западной Африки, $\mathrm{OOH}, \mathrm{EC}$, США, России и Китая, а возглавить ее могли бы преАставители Африканского союза.

Совбез ООН почти сразу же после этого продлия мандат миротворцев на полгода. Генеральный секретарь ООН Пан Ги Мун на пленарном засеАании Генассамблеи заявиц, что $\mathrm{OOH}$ не позволит проигравшему выборы президенту страны $\Lambda$. Гбагбо «заАушить правительство» победившего оппозиционного кандидата. Пан Ги Мун сослался на сообщения руководства миссии, что окружение $\Lambda$. Гбагбо уже проводит набор в свои ряды наемников, воевавших еще неАавно в Миберии. ООН начала частичную эвакуацию из страны своего персонала. В преАставительстве ООН в Кот-А'Ивуаре заявили, что «в связи с небезопасной ситуацией в стране и в соответствии со стандартными процедурами часть персонала организации будет временно размещена в Гамбии». Ожидается, что территорию страны покинет около 460 сотрудников организации. При этом в Кот-А’Ивуаре останется еще окомо 9 тыс. служащих $\mathrm{OOH}$, в том числе миротворцы и полицейские. В распространенном 29 декабря 2010 года заявлении главы управмения миротворческих операций $\mathrm{OOH}$ Алена $\Lambda$ е Руа бымо сказано, что «мирот- 


\section{КОНФАИКТОАОГИЯ / NOTA BENE • 1 (6) • 2016}

ворцы ООН в Кот-А’Ивуаре готовы защищать правитеиьство новоизбранного президента А. Уаттары и гражАанское население, ески политический кризис в стране перерастет в открытый конфмикт» [24]. Министр иностранных Аел Франции Мишель Амлио-Мари заявила, что французские военнослужащие имеют право защищать себя с помощью оружия, если они поАвергнутся атаке.

А через Ава Аня, 31 Аекабря начамьники штабов государств-участников Экономического сообщества стран Западной Африки (ЭКОВАС) на встрече в нигерийском Аагосе согласовали план, предусматривающий применение военной силы против провозгласившего себя президентом Гбагбо. «Начамьники штабов совещались во вторник и среду, чтобы разработать необходимый механизм. Если будут исчерпаны все среАства политического убежАения... ЭКОВАС симой возьмет власть из рук $\Lambda$. Гбагбо и передаст ее А. Уаттаре», - заявим представитель нигерийской армии полковник МохаммеА Йерима.

19 января 2011 года Совет Безопасности ООН еАиногласно приня резолюцию, в которой постановия Аополнительно направить в миссию ООН в Кот-А'Ивуаре 2000 миротворцев со сроком полномочий Ао 30 июня 2011 г. Резолюция была принята по преАложению генерамьного секретаря ООН Пан Ги Муна. СБ принял решение не только Аополнительно направить в миссию военнослужащих, но и Аислоцировать там 60 штатных полицейских на смену 60 полицейским ООН в цемях освобожАения ивуарийцев от вооруженной угрозы. В резолюции говорится, что СБ ООН глубоко озабочен насилием и нарушениями прав человека в Кот-А'Ивуаре, подчеркивается, что те, кто совершил преступления против сотруаников ООН и мирных гражАан, будут непременно привлечены к ответственности. СБ ООН потребовац от $\Lambda$. Гбагбо незамеАлительно без всяких условий снять блокаАу гостиницы, гАе размещена штаб-квартира Уаттары.

В начаме 2011 года в стране наступило относительное затишье. Но уже в марте политическое противостояние приобрело характер гражАанской войны. $\Lambda$. Гбагбо начац активно применять тяжелое оружие против сторонников А. Уаттары и французских миротворцев, послеАние открыто вступили в войну на стороне повстанцев. Пользуясь авиационной поААержкой французской армии и миротворческих сил ООН оппозиционеры в первых числах апреля установили контромь практически наА всей территорией страны и осадили опацьного президента в бункере его абиАжанской резиденции.

11 апреля французский спецназ при поААержке бронетехники и авиации сломих сопротивление немногих оставшихся сторонников $\Lambda$. Гбагбо. Он быц арестован и передан в руки оппозиции [25]. На слеАующий Аень низможенный презиАент в сопровожАении миротворцев OОН покинул город в неизвестном направлении. ПобеАой А. Уаттары завершился еще оАин этап острого политического конфмикта в КотА'Ивуаре. ОАнако можно преАположить, что завершился мишь опреАеленный этап противостояния. Причины конфмикта не устранены, а значит и неАовольство побежденных Ааст о себе знать в той или иной форме. ВАасть и оппозиция просто поменялись местами.

\section{Резюме}

В основе нынешнего конфмикта межат противоречия межАу условно-автохтонным населением региона и мигрантами, которые смогли занять более престижные социально-статусные ниши, чем те племенные общности, которые счита$\Lambda и$ себя «коренными» в этой стране. По своей сути нынешний конфмикт в Кот-А'Ивуаре - сугубо экономический, оАнако в силу социо-кумьтурного многообразия населения страны он может ошибочно трактоваться как «межэтнический» (интерпретации такого рода часто встречаются в СМИ), как конфессионамьный ими трайбамистский.

Говорить о «межэтническом» характере конфмикта - значит повторять стереотипы массового сознания, поскольку сам термин «этнос» и, соответственно, производные от него термины, корректно не определены. Употреблять этот термин в рассматриваемом контексте можно мишь в том случае, если поА ним мы будем понимать племенные сообщества или родственные социолингвистические группы. ОАнако в мюбом случае «этнические» коннотации Аишь закамуфмируют истинные причины конфмиктной ситуации, а, значит, мешают корректно опредекить его характер.

Впрочем, стоит привести точку зрения сенегальского политолога Франсуа Гоми, который считает, что в гвинейских и ивуарийских выборах есть нечто общее, - а именно, то «что этнический фактор продолжает играть важнейшую роль в африканской политике». ОАнако это сужАение мишь подтвержАает справеАливость неуместно- 


\section{ВНУТРИПОАИТИЧЕСКИЕ КОНФАИКТЫ}

сти этнических интерпретаций, поскольку автор этих строк и сам признает, что «большая часть политологов и африканистов избегают употребцять термин «еthnie», считая, что он перегружен нежелательными коннотациями» [10].

Нет Аостаточных оснований и Аля того, чтобы этот конфмикт преАставмять как конфмикт трайбалистский. Аействительно, конфмиктующие стороны принадлежат, как правило, к размичным пиеменным (социолингвистическим) общностям и участвуют в противостоянии в составе групп, обладающих племенной идентичностью. ОАнако в этом затянувшемся конфмикте трудно найти социокультурную мотивацию. СреАи конфмиктогенных факторов не просматриваются культурные (в том числе языковые) различия, и не эти разАичия служат яблоком раздора.

Может показаться, что несколько больше оснований имеется Аця попыток истолковать этот конфмикт как межконфессионацьный. Аействительно, противостоящие в нем стороны различаются по уАельному весу в каждой из них прозелитов ислама и христианства. ОАнако как среАи «южан», так и среАи «северян» есть и мусумьмане-сунниты, и христиане (католики и протестанты), и сторонники традиционных культов, и атеисты. В прессе иногАа мелькают сообщения о том, что помитики, персонифицирующие конфликт, иногАа пытались на разных стадиях его развертывания и пытаются сейчас приАать ему виАимость межконфессионального, но Аелается это из понятного жекания мобимизовать мощный идеологический ресурс и расширить электорамьную базу (а в иных скучаях - и с целью увеличить численность вооруженной клиентелы). Стоит принимать во внимание и тот факт, что рекигиозные Аеятеки как с той, так и с Аругой стороны (правящий архиепископ АбиАжана Ж. Кутва и глава Высшего совета имамов Кот-А’Ивуара шейх Б. Фофана) призывают своих прозекитов к сохранению мира и прекращению межАоусобицы. И в политической риторике противостоящих Аруг Аругу $\Lambda$. Гбагбо и А. Уаттара Ао сей поры не звучали открытые призывы к войне с «неверными». Ивуарийский политолог А. УэАрого тонко подметил, что «составляющие кризиса иАентичности сложнее, чем может показаться, что в преАполагаемое противостояние межАу мусульманами и христианами вовлечены скорее интегристские группы, чем массовое насемение» $[3$, с. 17]. Все это заставмяет усомниться в обоснованности трактовки рассматриваемого конфмикта как рекигиозного.

Если положить в основу его типологизации не кажущийся признак (пмеменную, языковую, кумьтурную и т.п. идентичность участников конфмикта), а реальную причину, обусловившую возникновение и Аинамику конфликтной ситуации, то ситуацию в Кот-А'Ивуаре следует интерпретировать как социацьно-экономический конфмикт межАу условно-автохтонным населением страны, укоренившимися мигрантами и мигрантами последних десятилетий $[26$, с. 226]. И как конфмикт межАу гражАанами и не гражАанами По Поводу влаАения среАствами Производства, прежАе всего, и по поводу гражАанских прав, которые Аолжны обеспечить равный Аоступ к экономическим ресурсам и ресурсам власти.

\section{БИБАИОГРАФИЯ}

1. Population Division of the Department of Economic and Social Affairs of the United Nations Secretariat // New York: United Nations. 2009. P. 381.

2. Африка. Этнический состав насемения // Народы мира. Историко-этнографический справочник. М., 1998. С. 558-560.

3. Ouédraogo D. Migrations circulaires et enjeux identitaires en Afrique de l'Ouest // Les Cahiers du Gres. Vol. 3. № 1.2002 . P. 9.

4. Dozon J.-P. La Côte d'ivoire entre démocratie, nationalisme et ethnonationalisme // Politique africaine. № 78.2000. Juin. P. 50.

5. Annan-Yao E. Immigration et identités culturelles en Afrique de l'Ouest // La population africaine au 21 ème siècle. UEPA. Troisième Conférence sur la population. Durban. 6-10 décembre 1999. P. 543-557.

6. Dozon J.-P. Aspects géopolitiques de la crise ivoirienne //http://www.cirpes.net/article119.html\#top

7. Kouame A. De la pénurie à la sous-utilisation de la main-d'oeuvre: un essai sur la problématique des ressources humaines en Côte d'Ivoire // Thèse de Doctorat Département de démographie. Université de Montréal. 1987. P. 57. 


\section{КОНФАИКТОАОГИЯ / NOTA ВЕNE • 1 (6) • 2016}

8. Coulibaly T. Lente décomposition en Côte-d'Ivoire // http://www.monde-diplomatique.fr /Archives / Novembre 2002

9. Les étrangers africains, otages du conflit en Côte d'Ivoire // http://www.connectionivoirienne. net $/ \mathrm{p}=47690$

10. Gomis F. Le retour du refoulé ethnique // Courrier international // http://www.courrierinternational. com/article/2010/12/09/le-retour-du-refoule-ethnique

11. Bazin L. La pandémie de l'«identité nationale» // http://www.monde-diplomatique.fr/2010/02/ BAZIN/18823FEVRIER 2010-Page 3

12. Blion R. Les Burkinabé de Côte d'Ivoire, entre intégration et circulation migratoire // Monde en Développement. V. 23. № 91. 1995. P. 81-93.

13. Sadio T. L'insertion professionnelle en milieu urbain ouestafricain // Rallu J. L et al. Anciennes et nouvelles minorités. INED-John Libbey Eurotex. Paris, 1997. P. 251-269.

14. Conflictologist // http://conflictologist.narod.ru/bsk02.html

15. Новый премьер-министр Кот-А’Ивуара представик предварительный список кандидатов в члены правительства // http://www.rian.ru/politics/20030211/316898.html

16. Dozon J.-P. Qui est Ivoirien et qui ne l'est pas? // http://www.amnesty.fr/index.php?/ amnesty/s_informer/la_chronique/mars_2006_sommaire/

17. США призывают президента Кот-А’Ивуара признать поражение на выборах // Информационное агантство Росбалт // http://www.rosbalt.ru/2010/12/10/799191.html

18. Военные ЭКОВАС согласовали план действий против главы Кот-А'Ивуара //http://news.mail. $\mathrm{ru} /$ politics/

19. Кот-А’Ивуар стоит на грани геноциАа, заявиц новый посол страны в ООН http://www.newsru. com/world/

20. Пастор о политическом конфмикте в африканском Кот-А’Ивуар // http://news.invictory.org/ issue 31905.html

21. Heintz A, Gouëset C. La crise en Côte d'Ivoire en cinq actes // http://www.lexpress.fr/actualite/ monde/afrique/la-crise-en-cote-d-ivoire-en-cinq-actes_947063.html

22. Тарасенко П. Кот-А’Ивуар в мешке Москве не нужен // Россия запретила Совбезу ООН признавать африканского оппозиционера победившим на выборах // Коммерсант. № 228.9 Аекабря 2010.

23. Heintz A. Les violences en Côte d'Ivoire sont dues à Sarkozy // http://interceder.net/list/ Cote-d\%E2\%80\%99Ivoire

24. Франция и Германия просят своих согражАан покинуть Кот-А’Ивуар // Информационное агантство Росбалт // //http://www.rosbalt.ru/2010/12/22/803566.html

25. Amère fin de partie pour Laurent Gbagbo - http://www.lefigaro.fr/international/2011/04/11/0100320110411ARTFIG00636-amere-fin-de-partie-pour-laurent-gbagbo.php

26. Филиппов В.Р. Ивуарский конфмикт: иррациональная «этничгность» или рациональная экономика? // Африка в контексте формирования новой системы международных отношений. Материалы Первой межвузовской научной конференции. М., 2012. С. 226-266.

27. Манойло А.В. Сирийский тупик «Арабской весны». // Вестн. Моск. Ун-та. Сер. 12. Политические науки. 2013. №6. С. 49-56.

28. Маноймо А.В. Политические конфмикты в межАународных отношениях и мировой политике. // Мир и Политика. 2013. №2. С. 71-82.

29. Филиппов В.Р. Политика Франции в Камеруне // Политика и Общество. - 2015. - 4. - С. 531 542. DOI: $10.7256 / 1812-8696.2015 .4 .14955$.

\section{REFERENCES (TRANSLITERATED)}

1. Population Division of the Department of Economic and Social Affairs of the United Nations Secretariat // New York: United Nations. 2009. P. 381.

2. Afrika. Etnicheskii sostav naseleniya // Narody mira. Istoriko-etnograficheskii spravochnik. M., 1998. S. 558-560.

3. Ouédraogo D. Migrations circulaires et enjeux identitaires en Afrique de l'Ouest // Les Cahiers du Gres. Vol. 3. № 1.2002 . P. 9. 


\section{ВНУТРИПОАИТИЧЕСКИЕ КОНФАИКТЫ}

4. Dozon J.-P. La Côte d'ivoire entre démocratie, nationalisme et ethnonationalisme // Politique africaine. №ㅇ 78. 2000. Juin. R. 50.

5. Annan-Yao E. Immigration et identités culturelles en Afrique de l'Ouest // La population africaine au 21 ème siècle. UEPA. Troisième Conférence sur la population. Durban. 6-10 décembre 1999. R. 543-557.

6. Dozon J.-P. Aspects géopolitiques de la crise ivoirienne //http://www.cirpes.net/article119.html\#top

7. Kouame A. De la pénurie à la sous-utilisation de la main-d'oeuvre: un essai sur la problématique des ressources humaines en Côte d'Ivoire // Thèse de Doctorat Département de démographie. Université de Montréal. 1987. R. 57.

8. Coulibaly T. Lente décomposition en Côte-d'Ivoire // http://www.monde-diplomatique.fr / Archives / Novembre 2002

9. Les étrangers africains, otages du conflit en Côte d'Ivoire // http://www.connectionivoirienne. net $/ \mathrm{p}=47690$

10. Gomis F.Le retour du refoulé ethnique // Courrier international // http://www.courrierinternational. $\mathrm{com} /$ article/2010/12/09/le-retour-du-refoule-ethnique

11. Bazin L. La pandémie de l'«identité nationale» // http://www.monde-diplomatique.fr/2010/02/ BAZIN/18823FEVRIER 2010-Page 3

12. Blion R. Les Burkinabé de Côte d'Ivoire, entre intégration et circulation migratoire // Monde en Développement. V. 23. № 91. 1995. R. 81-93.

13. Sadio T. L'insertion professionnelle en milieu urbain ouestafricain // Rallu J. L et al. Anciennes et nouvelles minorités. INED-John Libbey Eurotex. Paris, 1997. P. 251-269.

14. Sonflictologist // http://conflictologist.narod.ru/bsk02.html

15. Novyi prem'er-ministr Kot-d'Ivuara predstavil predvaritel'nyi spisok kandidatov v chleny pravitel'stva // http://www.rian.ru/politics/20030211/316898.html

16. Dozon J.-P. Qui est Ivoirien et qui ne l'est pas? // http://www.amnesty.fr/index.php?/ amnesty/s_informer/la_chronique/mars_2006_sommaire/

17. SShA prizyvayut prezidenta Kot-d'Ivuara priznat' porazhenie na vyborakh // Informatsionnoe agantstvo Rosbalt // http://www.rosbalt.ru/2010/12/10/799191.html

18. Voennye EKOVAS soglasovali plan deistvii protiv glavy Kot-d'Ivuara //http://news.mail.ru/politics/

19. Kot-d'Ivuar stoit na grani genotsida, zayavil novyi posol strany v OON http://www.newsru.com/world/

20. Pastor o politicheskom konflikte $\mathrm{v}$ afrikanskom Kot-d'Ivuar // http://news.invictory.org/issue31905. html

21. Heintz A, Gouëset C. La crise en Côte d'Ivoire en cinq actes // http://www.lexpress.fr/actualite/ monde/afrique/la-crise-en-cote-d-ivoire-en-cinq-actes_947063.html

22. Tarasenko P. Kot-d'Ivuar v meshke Moskve ne nuzhen // Rossiya zapretila Sovbezu OON priznavat' afrikanskogo oppozitsionera pobedivshim na vyborakh // Kommersant. № 228. 9 dekabrya 2010.

23. Heintz A. Les violences en Côte d'Ivoire sont dues à Sarkozy // http://interceder.net/list/ Cote-d\%E2\%80\%99Ivoire

24. Frantsiya i Germaniya prosyat svoikh sograzhdan pokinut' Kot-d'Ivuar // Informatsionnoe agantstvo Rosbalt // //http://www.rosbalt.ru/2010/12/22/803566.html

25. Amère fin de partie pour Laurent Gbagbo - http://www.lefigaro.fr/international/2011/04/11/0100320110411ARTFIG00636-amere-fin-de-partie-pour-laurent-gbagbo.php

26. Filippov V.R. Ivuarskii konflikt: irratsional'naya «etnichgnost'» ili ratsional'naya ekonomika? // Afrika v kontekste formirovaniya novoi sistemy mezhdunarodnykh otnoshenii. Materialy Pervoi mezhvuzovskoi nauchnoi konferentsii. M., 2012. S. 226-266.

27. Manoilo A.V. Siriiskii tupik «Arabskoi vesny». // Vestn. Mosk. Un-ta. Ser. 12. Politicheskie nauki. 2013. №6. S. 49-56.

28. Manoilo A.V. Politicheskie konflikty v mezhdunarodnykh otnosheniyakh i mirovoi politike. //Mir i Politika. 2013. №2. S. 71-82.

29. Filippov V.R. Politika Frantsii v Kamerune // Politika i Obshchestvo. - 2015. - 4. - C. 531 - 542. DOI: $10.7256 / 1812-8696.2015 .4 .14955$. 